\title{
Investigation of the impact of firm factors on stock returns of non-financial listed firms in kenya.
}

\author{
Cyprian Kinoti M'muriungi ${ }^{1}$, Prof. Willy Muturi' ${ }^{2}$, Dr. Oluoch Oluoch ${ }^{2}$ \\ ${ }^{1}$ Jomo Kenyatta University of Agriculture and Technology, Kenya,Thika Road, Nairobi \\ ${ }^{2}$ Jomo Kenyatta University of Agriculture and Technology, Kenya, Thika Road, Nairobi \\ ${ }^{3}$ Jomo Kenyatta University of Agriculture and Technology, Kenya, Thika Road, Nairobi
}

\begin{abstract}
:
Firms can be distinguished from one another on the basis of different financial and non-financial factors including firm size, firm value, leverage, earnings per share, cash flow and firm structure. These factors are unique to individual firms and influence the perception of investors towards the future performance of the firms. The aim of the study is to examine the impact of, Firm value, Earnings per share and Firm size on stock return for non-financial listed firms in Kenya. This study used census and covered all non-financial listed firms at the NSE between the years 2008 to 2016. The choice of this period was informed by various reforms undertaken at the NSE. These includes a rise in initial public offers (IPOs), additional offers (AOs), right issues, bonus issues and stock splits. These reforms have had great influence on stock returns. There are 44 non-financial listed firms in the Nairobi Securities Exchange. A number of studies in the empirical literature have documented that firm earnings scaled by market value of equity are related to average return. This study is meant to assess the sensitivity of empirical results of firm value, earnings per share and firm size on stock return for non-financial listed firms in Kenya. The study contributed to the body of knowledge in that non-financial listed firms have gained practical insights into the impact of firm factors under consideration on stock return thereby enriching their knowledge on how to increase overall positive results. The study was based on the problem that whereas there were various firm factors attributed to each firm, it was not clear how, firm value, earnings per share and firm size affect stock return for non-financial listed firms on stock markets particularly those with factors like in Nairobi Securities exchange. This was particularly because existing Empirical literature was scarce in this case. Panel regression model was applied to test the significance of the independent variables on dependent variable and unit root test, Co integration and granger causality test was applied for empirical testing of the data. Descriptive statistics was used to describe basic features of the data in the study.
\end{abstract}

Keywords: Factors, Stock returns, Firms, Non-financial.

\section{Introduction}

\section{Overview of Stock Returns and Firm Factors}

Firms thrive to sustain themselves in a variety of environments characterized with unsuitable economic situations in addition to the various firm factors. The effect of firm factors in developed economies varies from those in undeveloped or developing economies. There is a growing body of literature on the crucial roles of various firm factors on the average-return variability of common stocks (Simlai, 2009). Companies can be distinguished from one another on the basis of different financial and non-financial factors including, firm value, earnings per share, firm size and firm structure among others. These factors are unique to specific companies and raise a perception in the mind of the users of that information regarding the performance and the future of the firm. In reality, all critical decisions of firm management quickly reach markets and investors receive the information that consequently impact on the factors on stock returns which is an important issue regarding this financial research. 
Tahir, Sabir, Alam and Ismail (2013) assert that if identified individually, the crucial sources of average-return anomalies are firm size, firm value (book-to-market), past return (short-run return continuation and long-run return reversal), earnings momentum (post-earnings announcement drift), dispersion, accruals, credit risk, profitability and leverage etc. In this study, I reinvestigate the performance of the portfolio of common stock returns with respect to three popularly known firm factors: earnings per share, firm value and firm size (market equity, ME) as an intervening variable. More specifically, we revisit the role of common risk factors that are related to some of those firm factors and extrapolate the function of volatility persistence in the average stock returns.

The stock market along with debt markets are some of the means by which companies raise money for investment though most firms do not trade publicly. However, this allows businesses to be publicly traded, and raise additional financial capital for expansion by selling shares of ownership of the company in a public market (Cesari, Espenlaub, Khurshed \& Simkovic, 2010). The liquidity that an exchange affords the investors enables their holders to quickly and easily sell securities. This is an attractive feature of investing in stocks, compared to other less liquid investments such as property and other immoveable assets. Some companies actively increase liquidity by trading in their own shares (Simkovic, 2009).

The price of stocks and other assets is an important part of the dynamics of economic activity, and can influence or be an indicator of social mood. An economy where the stock market is on the rise is considered to be an up-and-coming economy. In fact, the stock market is often considered the primary indicator of a country's economic strength and development (Cutler, Poterba \& Summers, 1991). Rising share prices, for instance, tend to be associated with increased business investment and vice versa. Share prices also affect the wealth of households and their consumption. Therefore, central banks tend to keep an eye on the control and behavior of the stock market and, in general, on the smooth operation of financial system functions. Financial stability is the raison d'être of central banks. Exchanges also act as clearing houses for each transaction, meaning that they collect and deliver the shares, and guarantee payment to the seller of a security. This eliminates the risk to an individual buyer or seller that the counterparty could default on the transaction.

The smooth functioning of all these activities facilitates economic growth since lower costs and enterprise risks promote the production of goods and services as well as possibly employment. In this way, the financial system is assumed to contribute to increased prosperity, although some controversy exists as to whether the optimal financial system is bank-based or market-based (Alexander, Dhumale \& Eatwell, 2006). Recent events such as the Global Financial Crisis have prompted a heightened degree of scrutiny of the impact of the structure of stock markets (called market microstructure), in particular to the stability of the financial system and the transmission of systemic risk (Mandelbrot \& Hudson, 2006).

\subsection{The objectives of the study}

The objective of the study is to investigate the impact of firm factors on stock return as will be observed in non-financial listed firms in Kenya.

i. To establish the impact of firm value on stock returns of non-financial listed firms in Kenya.

ii. To determine the impact of earnings per share on stock returns of non-financial listed firms in Kenya.

iii. To assess the moderating impact of firm size on the relationship between firm factors and stock returns of non-financial listed firms in Kenya.

\subsection{Global Perspective}

Studies of stock market return and market characteristics are based on various theories that have been developed over the previous years. Some of the theories relate to the market efficiency and the ease with which firm factors information is reflected in the stock prices. There is a cost of capital problem whereby it's not clear which asset pricing model should be used. The capital assets pricing model (CAPM) of Sharpe (1964) and Lintner (1965) is the common choice. Recent evidence suggests, however that the CAPM is not a good description of the expected returns. As an alternative, Fama and French $(1993,1995)$ proposed a three-factor pricing 
model. But some argue that this model is empirically inspired and lacks strong theoretical foundation. There was a significant effect of stock and firm factors on stock returns during stock market crash in Indonesia in 1997, 2000 and 2008. In the USA, Simlai (2009) tested whether alternative volatility models' forecasts can further improve the common risk factors performance in explaining the fluctuations of portfolio stock returns sorted by two simple accounting ratios: firm size (ME) and bookto-market $(\mathrm{BE} / \mathrm{ME})$. In order to do so, the study followed the methodology pioneered by Fama and French in a series of seminal papers (Fama \& French 1992a, b, 1993). The patterns in the monthly and yearly average excess returns, with respect to two firm level characteristics documented, were consistent with earlier studies.

Simlai (2009) found that two risk factors based on the mimicking return for the firm size and book-tomarket ratios play a significant role in capturing strong variation in stock returns over an extended time period. Khurshed (2009) used a sample consisting of 240 UK IPOs issued during 2001-2005 and covering $95 \%$ of the total number of new issues. He found a positive relationship between the size of the firm and its long run performance (the larger size of the firm, in terms of the assets at the time of flotation, the better Long run performance of IPO will be).

Zaighum (2014) examined the impact of prespecified set of macroeconomic factors on firm's stock returns for nine nonfinancial sectors listed in Karachi Stock Exchange. The macroeconomic factors included are consumer price index, industrial production index, market returns, risk free return and money supply. The studied sample covered data from 2001 to 2011. Using pooled OLS, panel analysis showed that all studied sectors firm's stock returns have negative relationship with consumer price index, money supply and risk free rate, whereas industrial production index and market returns indicates a positive relationship (Zaighum, 2014).

Adedoyin (2011) investigated share price determination and corporate firm characteristics in a view to critically examine the significant effect corporate firm characteristics has in determining the price of shares listed on the Nigerian Stock Exchange. A panel data design was adopted using seventy-two companies from 2004-2009. Ordinary Least Square (OLS), fixed effect and random effect estimation technique were employed in the analysis with the use of Gretel econometric analytical tool. The result indicated that the size of the firm has the most significant effect on share price determination in the two models adapted for the study. The study recommended that investors should be critical and objective in considering corporate firm factors in making investment decisions. Also, Managements and board members should aim at improving earnings which were rated through the literature reviewed to be a major determinant of share price.

Fama and French (1992) analyzed all non- financial US IPO firms issued during the period (1962-1989). They excluded financial firms because the high leverage that is normal for these firms probably do not have the same meaning for non-financial firms. They studied the joint roles of market Beta $(\beta)$, size, $\mathrm{E} / \mathrm{P}$, leverage, and book - to-market equity in the cross - section of average stock return. They found that being used alone or in combination with other variables (the slope in the regression of a stock return on a market return) has little information about average return, firm size; E/P, leverage, and book to market equity have explanatory power. In combination firm size, book to market equity seem to absorb the apparent roles of leverage and E/P (earning/price) in average return. Also, Fama and French document that common stock returns are related to firm size and book to market ratio.

Gomes, Kogan, and Zhang (2001) link expected returns to firm size and book-to-market in a dynamic general equilibrium production economy. Firm size and book-to-market can predict returns because they are correlated with the firm's systematic risk. XiaoMing and Xiaoguang (2010) examined the effects of firm characteristics on stock returns for China's investable firms specifying 12 alternative panel regression models to ensure the robustness of results, taking into account several issues e.g. errors in beta estimates, possible flat return-beta relation, and results being sensitive to different proxies for market portfolios, outlier problem, and the possible January effect. 


\subsection{Local Perspective}

Some firms perform better than others in financial management and profitability while most of the researches in Kenya have been generalizing the correlation between these variables with all the firms listed at the NSE (Mwangi et al., 2014; Maina \& Kondongo, 2013) and this may give wrong conclusions. Some firms are underperforming and facing financial or managerial problems e.g. CMC Holdings faced boardroom challenges and Mumias Sugar moved into losses, while Unga group and Uchumi profits fell by $43 \%$ and $35 \%$ respectively as per their half year results for the period ending December 2012. The most consistent in terms of profitability and performance are the firms under NSE 20 Share Index and are the best twenty firms at the NSE.

Barako (2007) investigated the determinants of voluntary disclosures in Kenyan companies' annual reports by examining: firm size, leverage, type of audit firm, profitability and liquidity. The study found that in almost all disclosure studies, company size has featured as an important determinant of disclosure levels (Belkaoui-Riahi, 2001; Lang \& Lundholm, 2003; Owusu-Ansah, 2008; Wallace \& Naser, 2005).

Omondi and Muturi (2013) did a study on Factors Affecting the Financial Performance of Listed Companies at the Nairobi Securities Exchange in Kenya. The study adopted an explanatory research design and 29 listed firms (excluding listed banks and insurance companies) which have consistently been operating at the Nairobi securities exchange during the period 2006-2012 using Pearson correlation and multiple-regression. Study findings showed that leverage had a significant negative effect on financial performance. The study suggested that there is need to determine an optimal debt level that balances the benefits of debt against the costs of debt and developing sound techniques of managing current assets to ensure that insufficient and unnecessary funds are not invested in current assets as maintaining a balance between short-term assets and short-term liabilities is critical (Omondi \& Muturi, 2013).

Muiva (2014) examined the relevance of firm fundamentals in explaining stock returns of non- financial firms listed at the Nairobi Securities Exchange. The specific objectives of the study were to determine the relationship between stock returns and change in total assets, change in revenue growth and change in leverage and to determine the effect of change in total assets, change in revenue and change in leverage on stock returns. The study found a weak positive correlation between stock returns and change in total assets, while change in revenue and change in financial leverage exhibited a negative relationship with stock returns. However, the relationship between stock returns, change in total assets, change in revenue and change in financial leverage was found not to be significant. The study concluded that change in total assets, change in revenue and change in financial leverage cannot be used to meaningfully estimate stock returns for non-financial firms listed at the Nairobi Securities Exchange. Investors should not rely on information contained in change in total assets, change in revenue and change in financial leverage in selecting their investment stock at the Nairobi Securities Exchange. Also, managers cannot rely on changes in these variables as indicators of the effect of their decisions on value of their firms (Muiva, 2014).

\subsection{Capital Structure Substitution Theory}

Capital Structure Substitution Theory Timmer, Jan (2011) describes the relationship between earnings, stock prices and capital structure of public companies. The CSS theory hypothesizes that the management of public companies manipulate capital structure such that earnings per share (EPS) are maximized. Management have an incentive to do so because shareholders and analysts value earnings per share (EPS) growth. The theory is used to explain trends in capital structure, stock market valuation, dividends policy, the monetary transaction mechanism, and stock volatility and provides an alternative to Modigliani-Miller theorem that has limited descriptive validity in real markets where share repurchases are allowed. The investors can use the CSS theory to identify the undervalued stock (Godwin, Steve, 2015), Zurcher, Ulrik Ardal (2014).

The CSS theory assumes that, company management can freely change the capital structure of the company-substituting bonds for stock and 
vice versa - on day to day basis and on small denominations without paying transaction costs. Companies can therefore decide to buy back one single share for the current market price and finance this by issuing one extra corporate bond or do the reverse.

\subsection{Capital Structure Theory - Net Income Approach}

Capital structure is the proportion of debt and equity in which a corporate finances its business. The capital structure of a company/firm plays a very important role in determining the value of a firm (Dimitrov, 2011). For finding the optimum capital structure in order to maximize shareholder's wealth or value of the firm, different theories (approaches) have evolved. One of the traditional approaches is the Net Income Approach (Schaeffer, 2013). Net Income Approach was presented by Durand. The theory suggests increasing value of the firm by decreasing the overall cost of capital which is measured in terms of Weighted Average Cost of Capital (Armitage, 2014). This can be done by having a higher proportion of debt, which is a cheaper source of finance compared to equity finance. According to Net Income Approach, change in the financial leverage of a firm will lead to a corresponding change in the Weighted Average Cost of Capital (WACC) and also the value of the company. Velez-Pareja (2012).

Net Income Approach makes certain assumptions which are as follows: the increase in debt will not affect the confidence levels of the investors, the cost of debt is less than the cost of equity and that there are no taxes levied (Erturk \& Nejadmalayeri, 2009). Maximization of shareholders' wealth is prime objective of a financial manager. The same may be achieved if an optimal capital structure is designed for the company. Planning a capital structure is a highly psychological, complex and qualitative process Bhatnagar, Kumari \& Sharma (2015). It involves balancing the shareholders' expectations (risk \& returns) and capital requirements of the firm. Earnings are a function of investment decisions and operating efficiencies. Value of a firm depends upon earnings of a firm and its cost of capital (Pietrovito, 2012). Capital structure cannot affect the total earnings of a firm (EBIT), but it can affect the residual shareholders' earnings. Value of a Firm is directly co-related with the maximization of shareholders' wealth and thus it (value of a firm) varies due to changes in the earnings of a company or its cost of capital, or both (Anthony, 2011). The value of firm is derived by capitalizing the earnings by its cost of capital (WACC). Value of Firm = Earnings / WACC (WACC is a function of a company's capital structure). In this study, firm value will be measured by book to market value of equity.

\subsection{Trade off Theory}

The Trade-off theory of capital structure is the idea that a company chooses how much debt finance to use by balancing the costs and benefits. Trade off theory predicts that larger firms tend to be more diversified and hence likely to be less susceptible to financial distress. Further, if maintaining control is important, then it is likely that firms achieve larger size through debt rather than equity financing. Thus, control considerations also support positive correlation between firm size and debt. Ferri and Jones (2009) found that larger firms are likely to use more debt. Therefore, a positive association is expected between firm's size and leverage. Direct financial distress cost is inversely related to firm size (Cassar \& Holmes, 2003). The ratio of direct bankruptcy costs to the value of the firm decreases as the value of firm increases. The impact of direct costs of bankruptcy on borrowing decisions of large firms is negligible. Larger firms are more diversified Ang et al., (2012), and they have easier access to capital markets, and borrow at more favorable interest rates. Chittenden et al., (2006) argued that the large firms have lower agency costs associated with the asset substitution and under investment problems, which mostly arise from the conflicting interests of shareholders and bondholders. Further, the smaller firms are more likely to be liquidated when they are in financial distress (Ozkan, 1996). Firm size is closely related to risk and bankruptcy costs. All such considerations suggest a positive relationship between the firm size, which is measured as the volume of total assets of firms, the leverage ratio and market capitalization.

\subsection{Conceptual Framework}




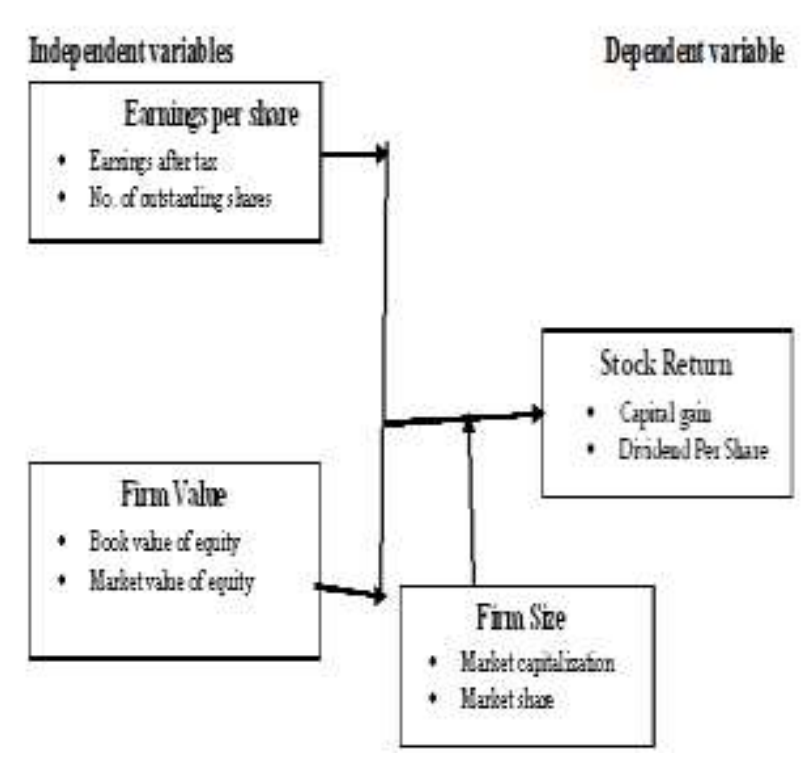

\subsection{Earnings per Share}

Tahir, S.H., Sabir, H.M., Alam, T., and Ismail, A. (2013) investigated the impact of earnings per share on stock return of non-financial listed companies in Pakistani. By using multiple regression analysis model to test the significance of EPS on stock return, it was concluded that EPS has a positive significance on stock return. EPS is one of the investment tools used to evaluate a company's performance either in the short or long-term.

Seetharaman and John Rudolph Raji (2011) assessed the impact of an announcement of earnings per share (EPS) on stock prices of a listed bank in Malaysia. After analyzing the time series data of public bank Berhad over a 19 year period, the results indicated that the impact of EPS was significant on the volatility and drift in the movement of its stock prices. This finding was consistent with the work done by Eilifsen et al. (1999) who found a significant reduction in stock price volatility in the post-announcement period relative to the preannouncement period for companies traded on the Oslo Stock Exchange in the period 19901995.Pushpa Dhatt \& Sumangala JK (2012) investigated the impact of EPS of the market value of an equity share. The study is based on the crosssectional time series data of 50 companies. The study concluded that EPS impacts the market value of an equity share in the Indian context.

\subsection{Firm Value}

Huseyin (2008) justified the reason behind the practice of counter cyclical variations of expected value Premium. He adopted the two-state Markov switching framework of Perez and Timmermann (2000) that in recessions, the expected excess returns of value stocks were most strongly affected, and the expected excess returns of growth stocks were least affected, by worsening economic conditions as measured by higher one-month Treasury bill rates and higher default spreads.

Safi and Faisal (2008) examined empirical causal relationships between trading volume, stock return and return volatility in Pakistan's stock market. The study focused on whether information about trading volume is useful in improving forecasts of returns and return volatility in a dynamic environment. The study found that there is a feedback relationship between trading volume and stock returns, which is consistent with the theoretical models that imply information content of volume affects future returns. These findings supported the argument of Gallant, Rossi and Tauchen (2002) that more can be learned about the stock market through studying the joint dynamics of stock prices and trading volume than by focusing only on the single dynamics of stock prices.

In Kenya, Ooko (2011) did a study on Value Premium and Industry Type: Evidence from the Nairobi Stock Exchange using portfolio formation. The study found that investors will always want to invest in projects that can guarantee higher returns than others, holding risk constant. They therefore tend to employ strategies that will contribute to the realization of higher returns. One of the most frequently used strategies is value investing where investors purchase value stocks rather than growth stocks in order to benefit from potential long term performance of value stocks in the form of superior average returns. The study also found that when stocks are grouped according to industries, there still exists value premium. Therefore, for a value strategist at the NSE, industrial and allied sector stocks are the best to invest in while agricultural sector stocks are the worst to invest in. The findings are also consistent with findings from similar studies in other markets in the world. Previous studies show that for 60 plus years value has outperformed growth. The conclusion of this study is that there exists a value premium at the N.S.E when stocks are sorted on the basis of Book to Market ratio. 
However, there exists no significant difference in value premium across industries. This implies industry type is not a significant determinant of value premium. This is consistent with other studies done in Kenya. Muhoro (2004) tested a value premium of 0.64 for the period 1999-2002 at the NSE and Ngigi (2006) also tested the existence of value premium at the NSE.

Athanassakos (2009) in his study of the Canadian market, documents a consistently strong value premium over the sample period, which persists in both bull and bear markets, as well as in recessions and recoveries. He shows that value premium is not driven by a particular industry as the value premium is positive for most industries. He also observes that it is only in the cases of positive value premiums that the difference between the value and growth stocks annual returns is statistically significant and not when the value premium is negative. Hence, he concludes that value premium seems to be pervasive and not concentrated only in a few sectors of the economy. Athanassakos (2009) however used P/E and P/BV to sort out stocks into value and growth.

Thuku (2009) in his study to establish the existence of value premium and the effect of size at the NSE based on both $\mathrm{B} / \mathrm{M}$ and $\mathrm{E} / \mathrm{P}$ ratio, found the existence of value premium at NSE. The test was conducted at 0.05 confidence level. He used both $\mathrm{B} / \mathrm{M}$ ratio and $\mathrm{E} / \mathrm{P}$ in differentiating growth from value stock. He first created portfolios which were based on firm size (market capitalization) in order to differentiate between small capitalized firms and large capitalized firms. Secondly, portfolios were created based on $\mathrm{B} / \mathrm{M}$ and $\mathrm{E} / \mathrm{P}$ ratios to categorize stock as either growth or value stock. He found out that small value stocks perform better than the large value stock when portfolios are ranked according to $\mathrm{P} / \mathrm{E}$ ratio as compared to when they are sorted out based on $\mathrm{B} / \mathrm{M}$ ratio. The difference is however very small to be significant to fail the 0.5 confidence level.

\subsection{Firm Size}

Previous studies in finance have shown that company size can predict the future stock price (Simerly \& Li, 2000). For instance, Hvide and Moen (2007) in their study concluded that larger firms have better performance. Flamini et.al., (2009) suggested that bigger firms are more competitive than smaller firms in harnessing economies of scale in transactions and enjoy a higher level of profits. Athanasoglou et al., (2005) assert that increase in company size increases the performance of the bank. Almajali et al., (2012) argued that the size of the firm can affect its financial performance. However, for firms that become exceptionally large, the effect of size could be negative due to bureaucratic and other reasons (Yuqi 2007).

In India, Kumar and Sehgal (2004) studied the relationship between company characteristics i.e. firm size effect, value effect and stock classification effect and common stock returns and found that size effect is the relationship between company size and common stock return. This implies that small firm stock should significantly outperform stocks of big firms. Size effect can mainly be attributed to the following: small firms are relatively ignored by investors; they are less researched upon; they exhibit less liquidity and hence their betas are generally under-estimated; they have concentration of management ownership; they do not have diversified operations, and they have weak management, less committed customer base, high labor turnover, poor technology, etc. As there are a variety of ways in which one can measure company size, the following alternatives can be used: Market Capitalization (MC), Total Asset (TA), Enterprise Value (EV), and Net Sales (NS).

Amir (2011) examined the return of the size anomaly in the German stock market by using an instrumental variable estimation to address Berk's critique of a simultaneity bias in prior studies on the small firm effect and to investigate the economic rationale behind firm size as an explanatory variable for the variation in stock returns. The study confirmed an inverse relationship between firm size and return, yet with two qualifications. First, the link was stronger during the bull market period (prosperous) than during the bear market period (slump); and second, the momentum effect surpasses the size effect at least in a risk-based specification. The results indicate that the marginal effect of firm size on stock returns is conditional on the firm's past performance. The results also showed that firm size captures firm characteristic components in stock 
returns and that this regularity could not be explained by differences in systematic variations.

Aksu and Onder (2000) explore the relationship of size and book-to-market ratio with stock returns and with firm-specific and macro-economic fundamentals in the Istanbul Stock Exchange (ISE). The study applied two different asset pricing models, the one factor CAPM and the three-factor Fama and French model, to individual security returns, size and book-to-market sorted portfolios. The study found both size and book-to-market effects to be significant, but the former has a higher explanatory power. Aksu and Onder (2000) also evaluated the firm-specific risk and return characteristics of the extreme portfolios in different states of the Turkish economy and look at the relationship between the Fama and French factors and macro-economic indicators. The results revealed some new empirical regularities in the Istanbul Stock Exchange (ISE) and support the Fama and French findings to justify models for additional risk factors in returns.

According to Drew, Naughton and Veeraraghavan (2003), small and growth firms generate superior stock returns than big and value firms. Therefore, they report that the value effect is not as pervasive as was found for the US portfolios and other international markets. However, they only run the one-stage time series regressions using mimic portfolios based on size and book-to-market equity. No cross-sectional pricing analysis was conducted. Rutledge, Zhang, and Karim (2008) examine the relationship between firm size and excess stock returns in the Chinese stock markets in both a bull and bear market. Their results indicate that a size effect exists over the 6-year period from 1998 to 2003. Moreover, small firms are found to have a stronger reaction to the direction of the market than large firms. Small firms have significantly greater positive excess returns than large firms during the bull market and significantly greater negative returns during the bear market period. The value effect was not examined. Eun and Huang (2007) documented that the market risk is not priced; firm size and the book-to-market ratio are systematically related to stock returns. Nevertheless, the high correlations among their explanatory variables - market beta, natural logarithms of market value and natural logarithms of book-to-market ratio of individual firms, make the slopes in the regressions hard to interpret.

\subsection{Performance of Non-Financial Listed Companies}

Omondi and Muturi (2013) assert that the financial performance of companies is a subject that has attracted a lot of attention, comments and interests from both financial experts, researchers, the general public and the management of corporate entities. Yet, selecting out the most successful firms has always proved to be a difficult task to many as a firm may have a high level of profitability, but at the same time be in a very bad situation regarding its liquidity. The Financial performance of a firm can be analyzed in terms of profitability, dividend growth, sales turnover, asset base, capital employed among others (Omondi \& Muturi, 2013).

However, there is still debate among several disciplines regarding how the performance of firms should be measured and the factors that affect financial performance of companies (Liargovas \& Skandalis, 2008). A single factor cannot reflect every aspect of a company performance and therefore the use of several factors allows a better evaluation of the financial profile of firms. According to Iswatia, \& Anshoria (2007) performance is the function of the ability of an organization to gain and manage the resources in several different ways to develop competitive advantage. Financial performance emphasizes on variables related directly to financial report. The Capital market plays a critical role in the economy by facilitating mobilization and allocation of capital resources to finance long term productive investments. Almajali et al. (2012) argues that there are various measures of financial performance. For instance, return on sales reveals how much a company earns in relation to its sales, return on assets explain a firm's ability to make use of its assets and return on equity reveals what return investors take for their investments.

\subsection{Critique of Existing Literature}


According to a study conducted by Kumar and Sehgal (2004) on Company Characteristics and Common Stock Returns in India, size effect can mainly be attributed to the fact that small firms are relatively ignored by investors; they are less researched upon; they exhibit less liquidity and hence their betas are generally under-estimated; they have concentration of management ownership; they do not have diversified operations, and they have weak management, less committed customer base. Amir (2011) confirmed that firm size captures firm characteristic components in stock returns and that this regularity could not be explained by differences in systematic variations. The studies by Kumar and Sehgal (2004) and Amir (2011) have informed the current study by guiding the researcher in what to expect in the study findings, however, the study was done in Asia and an African perspective is of much essence.

The study by Huseyin (2008) which justified the reason behind the practice of counter cyclical variations of expected value premium adopted the two-state Markov switching framework of Perez and Timmermann (2000). The current study however will adopt the panel regression model which will be applied to test the significance of independent variables on dependent variable. Tahir, Sabir, Alam and Ismail (2013) conducted a study on Impact of Firm's Characteristics on Stock Return in Pakistan which has empirically enriched the current study. However, the study was done in Pakistan and a Kenyan perspective is of paramount importance.

\subsection{Materials and Methods}

For the purpose of analysis first of all stock price data of all non-financial listed companies will be collected on the last financial day of the Company i.e. in December of each year. The share price data will then be converted into return data to make it suitable for further estimation. For this purpose, Holding Period Yield (Stock returns) will be calculated for each year using the formula:

$$
H P Y=\frac{P e-P b+D}{P b}
$$

Where $\mathrm{Pe}=$ Ending Price of the stock in current year, $\mathrm{P}_{\mathrm{b}}$ is beginning price of stock in the current year and $\mathrm{D}$ is the dividend earned in the year.

\subsection{Model Specification}

A Panel regression model will be applied to test the significance of independent variables on dependent variable. The model will be as follows:

$\mathrm{SRn}=\alpha+\beta_{1}(\mathrm{EPS})+\beta_{2}(\mathrm{FV})+\varepsilon$

In the above model, the stock return (SRn) is dependent variable and earnings per share (EPS), firm value (FV)are independent variables. The $\beta$ s are the parameters to be estimated and $\varepsilon$ is the error term.

To test the moderating effect of firm size, moderated panel regression (MPR) analysis, an inferential procedure consisting of comparing two different least-squares regression equations (Aguinis, 2004), will be utilized. Prior to conducting the MPR analysis, preliminary analysis will be conducted to ensure that there will be no violation of the assumptions of normality, linearity and homogeneity of error variance (Sazali et al., 2009). In this study, the following model will be used to represent the variables in the ordinary least-squares (OLS) model: (OLS model): $Y=\beta 0+\beta_{1} X+\beta_{2} Z+\varepsilon$

To determine the presence of moderating effect, the OLS model will then be compared with the MPR model which is represented below:

(MPR model): $Y=\beta_{0}+\beta_{1} X+\beta_{2} Z+\beta_{3} X^{*} Z+\varepsilon$

Where;

$\mathrm{Y}=$ Stock returns of non-financial listed firms,

$\mathrm{X}=$ the two variables (EPS, firm value)

$\mathrm{Z}=\mathrm{a}$ hypothesized binary grouping moderator (presence or absence of firm size)

$\mathrm{X}^{*} \mathrm{Z}=$ the product between the predictors (The two variables $*$ firm size),

$\beta_{0}=$ the intercept of the line-of-best fit which represents the value of $\mathrm{Y}$ when $\mathrm{X}, \mathrm{Z}=0$,

$\beta_{1}=$ the least-squares estimate of the population regression coefficient for $\mathrm{X}$,

$\beta_{2}=$ the least-squares estimate of the population regression coefficient for $\mathrm{Z}$,

$\beta_{3}=$ the sample-base least-squares estimates of the population regression coefficient for the product term, and

$\varepsilon=$ the error term. 


\subsubsection{Variable operationalization}

Table 3. 1: Variable operationalization Matrix

\begin{tabular}{|l|l|l|c|}
\hline & Variable & Operationalization & Measurement \\
\hline Dependent variable & Stock Return & $\begin{array}{l}\underline{\mathrm{P}}_{\mathrm{e}}-\mathrm{P}_{\mathrm{b}}+\mathrm{D} \\
\mathrm{P}_{\mathrm{b}}\end{array}$ & Ratio \\
\hline Independent variables & Earnings Per Share & $\begin{array}{l}\text { Earnings Per Share } \\
\text { EPS= EAT/ No of Shares }\end{array}$ & Ratio \\
\hline & Firm Value & $\begin{array}{l}\text { Market to Book value of } \\
\text { Equity } \\
\text { MBVE=MVE/BVE }\end{array}$ & Ratio \\
\hline
\end{tabular}

Where;

$\mathrm{P}_{\mathrm{e}}=$ Ending price, $\mathrm{P}_{\mathrm{b}}=$ Beginning price, $\mathrm{D}=$ Dividend per share, EAT=Earnings After Tax, EPS=Earnings per Share, MBVE=Market to Book Value of Equity, MVE=Market Value of Equity, BVE=Book Value of Equity.

\section{Unit Root Test}

The data will be of time series in nature. It will be necessary to check its stationarity before the application of any technique. For this purpose, the most frequently used Augmented Dickey Fuller (ADF) test will be applied.

\section{Co-integration Test}

Co-integration analysis was first used by Johansen \& Josuilius. It can be applied to test the existence of R co-integrating vectors. (1) Maximal Eigen value, the maximal Eigen value test the null hypothesis that the number of Co-integrating relationships is less than or equal to or against the alternative $r+1$. (2) The Trace statistics. The trace statistic is the null hypothesis of $\mathrm{r}$ Co-integrating against the alternative of $r$ or more Co-integrating vectors.

\section{Granger Causality Test}

In the next step, Granger Causality test will be applied. It is the test which helps researchers to determine the direction of causes i.e. whether $\mathrm{Y} \leftrightarrow$

$\mathrm{X}$. In order to test this hypothesis, the $\mathrm{F}$ test in the form given below will be applied.

$\mathrm{F}=(\mathrm{RSSr}-\mathrm{RSSur}) / \mathrm{M} \div(\mathrm{RSSur} / \mathrm{n}-\mathrm{k})$

Where RSSr is the restricted residual sum of squares, RSSur is the unrestricted residual sum of squares, $\mathrm{M}$ is the lag term and $\mathrm{n}-\mathrm{k}$ is the degree of freedom.

If the computed value exceeds critical value of $\mathrm{F}$ at some chosen level of significance, then null hypothesis is rejected and it is concluded that $\mathrm{Y}$ is the cause of $X$. Such test could be repeated for identification of cause for other variables as well.

\section{Descriptive Statistics}

Descriptive statistics will be used to describe the basic features of the data in the study. They provide simple summaries about the sample and the measures. Simple graphical analysis will form the basis of virtually every quantitative analysis of data. Descriptive statistics will explain the behavior of stock returns. It will also explain the volatility in returns. Descriptive statistics will include mean of returns, maximum and minimum values, Standard Deviation, Variance and coefficient of variation.

\subsection{Results and Discussion}

\subsection{Descriptive Statistics}

Table 4.1 below gives the summary descriptive statistics of the dependent and independent variables of the sample. 


\begin{tabular}{|c|c|c|c|c|}
\hline \multicolumn{5}{|c|}{ Descriptive Statistics } \\
\hline & Count & Mean & Standard Deviation & $\begin{array}{c}\text { Coefficient of } \\
\text { Variation }\end{array}$ \\
\hline $\begin{array}{l}\text { STOCK } \\
\text { RETURNS }\end{array}$ & 374 & 2.312 & 29.9370 & $1294.6 \%$ \\
\hline $\begin{array}{l}\text { EARNINGS PER } \\
\text { SHARE }\end{array}$ & 374 & 6.863 & 13.9539 & $203.3 \%$ \\
\hline FIRM VALUE & 374 & $\begin{array}{c}3377.8358486075190 \\
00\end{array}$ & 35297.745660759660000 & $1045.0 \%$ \\
\hline
\end{tabular}

From table 4.1,the mean value of stock return was 2.312 with standard deviation of 29.74 indicating higher volatility in the stock returns. Firm value has a mean value of 3377.84 and a standard deviation of 35297.75. Average earnings per share is 6.863 with the lower coefficient of variation of 203.3 showing low dispersion.

\subsection{Unit Root Tests}

Unit root tests were conducted using Augmented Dickey Fuller (ADF) test to ensure that the variables had no unit roots. The tables below show the results from the tests.

\section{Table 4.2 Unit roots}

\begin{tabular}{|l|l|l|}
\hline & ADF(level) & Philips-Perron (level) \\
\hline Stock returns & -7.02 & -19.261 \\
\hline Firm size & -7.162 & -19.123 \\
\hline Firm value & -7.262 & -19.151 \\
\hline Earnings per share & -6.848 & -16.798 \\
\hline
\end{tabular}

ADF results for all the six variables, (stock returns, leverage, firm size, firm value, cash flow and earnings per share) indicates that the data was stationary since the values are below zero.

\subsection{Granger causality test}

To test causality, two regression equations were set.

The approach causality used was the past

\section{Table 4.3 Granger causality statistics}

\begin{tabular}{|l|l|l|l|}
\hline Pair wise granger causality test & & & \\
\hline Null hypothesis & Obs & f-statistics & Prob \\
\hline Stock returns does not granger causes firm value & 377 & 0.0041 & 0.995886 \\
\hline Firm value does not granger causes stock returns & & 0.0000 & 1.000 \\
\hline Stock returns does not granger causes firm size & 377 & 0.0392 & 0.961358 \\
\hline Firm size does not granger causes stock returns & & 0.000 & 1.000 \\
\hline Firm size does not granger causes firm value & 377 & 0.6768 & 0.507011 \\
\hline Firm value does not granger causes firm size & & 4.3929 & 0.012715 \\
\hline
\end{tabular}

Decision rule: reject $\mathrm{H} 0$ if $\mathrm{P}$-value $<0.05$.

In all the variables we do not reject the null hypothesis hence there is no granger causality reject the null hypothesis hence there is unidirectional causality. 

data from the year 2008 to 2016 for the 44 nonfinancial listed companies in Kenya.

Table 4.4 Panel regression model summary

\begin{tabular}{|l|l|l|l|l|}
\hline \multicolumn{3}{|l|}{ Model Summary } \\
\hline $\begin{array}{l}\text { Mod } \\
\text { l }\end{array}$ & $\mathrm{R}$ & $\begin{array}{l}\mathrm{R} \\
\text { Square }\end{array}$ & $\begin{array}{l}\text { Adjusted R } \\
\text { Square }\end{array}$ & $\begin{array}{l}\text { Std. Error } \\
\text { of the } \\
\text { Estimate }\end{array}$ \\
\hline 1 & $.794^{\mathrm{a}}$ & .63 & .53 & $\begin{array}{l}.16767173 \\
0911196\end{array}$ \\
\hline $\begin{array}{l}\text { a. Predictors: (Constant), Cashflow, Firm value, } \\
\text { Leverage, Earning per share }\end{array}$
\end{tabular}

From table 4.4, R-squared (co-efficient of determination) is $63 \%$ implying that the predictors $63 \%$. Therefore the panel regression model has a good fit. in the model ( Firm value, Earning per share and Firm Size) explains the variation of stock returns by

Table 4.5 t-test

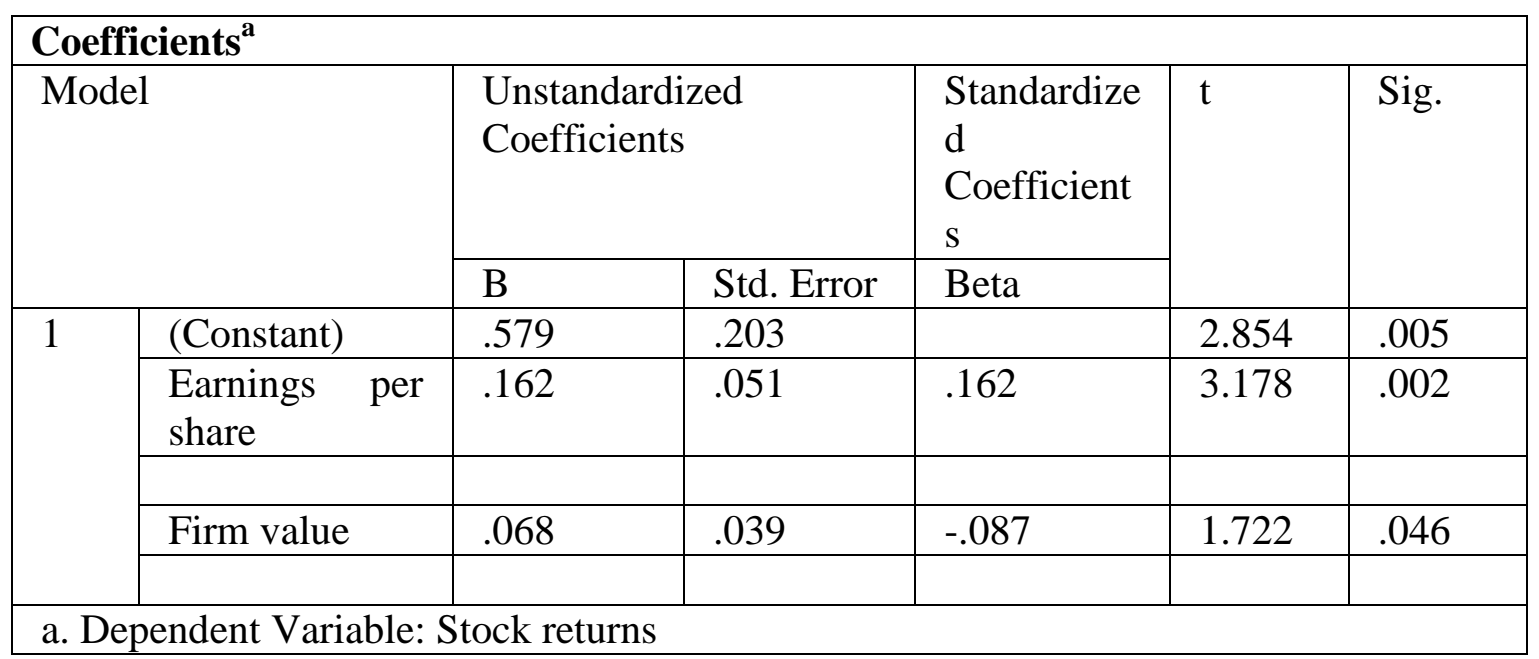

The panel regression result shows that parameter estimate for earning per share and firm value were found to have positive impact on stock returns. At 95\% level of significance these effects were also significant. From the model summary R-squared was 0.63 , an indication that approximately $63 \%$ variation in the stock returns of non-financial listed companies in Kenya is explained by variations of firm value and earning per share. Therefore, this model provide a good fit. It is also necessary to explore the OLS and the Moderated panel regression
(MPR) models where the moderating variables will be considered as well as the interactions of the variables.

\subsection{Impact of firm value to stock returns.}

Using the ordinary least squares method and moderated panel regression, the effect of Firm value with absence and with presence of firm size and interactions was determined and discussed.

4.5.1 Impact of Firm Value to stock returns with the absence of firm size and interactions

Table 4.5a fitness test of firm value to stock returns with absence of firm size and interactions

\begin{tabular}{|l|l|l|l|l|}
\hline \multicolumn{3}{|l|}{ Model Summary } \\
\hline $\begin{array}{l}\text { Mod } \\
\text { el }\end{array}$ & $\mathrm{R}$ & $\begin{array}{l}\mathrm{R} \\
\text { Square }\end{array}$ & $\begin{array}{l}\text { Adjusted R } \\
\text { Square }\end{array}$ & $\begin{array}{l}\text { Std. Error } \\
\text { of the } \\
\text { Estimate }\end{array}$ \\
\hline 1 & $.872^{\mathrm{a}}$ & .76 & .73 & $\begin{array}{l}.17042450 \\
1817731\end{array}$ \\
\hline
\end{tabular}


a. Predictors: (Constant), Firm value

Table 4.5b $t$ - test for firm value to stock returns with absence of firm size and interactions

\begin{tabular}{|c|c|c|c|c|c|c|}
\hline \multicolumn{7}{|c|}{ Coefficients $^{\mathrm{a}}$} \\
\hline \multirow{2}{*}{\multicolumn{2}{|c|}{ Model }} & \multicolumn{2}{|c|}{$\begin{array}{l}\text { Unstandardized } \\
\text { Coefficients }\end{array}$} & \multirow{2}{*}{$\begin{array}{l}\text { Standardize } \\
\text { d } \\
\text { Coefficient } \\
\text { s } \\
\text { Beta } \\
\end{array}$} & \multirow[t]{2}{*}{$\mathrm{t}$} & \multirow[t]{2}{*}{ Sig. } \\
\hline & & B & Std. Error & & & \\
\hline \multirow[t]{2}{*}{1} & $\begin{array}{l}\text { (Consta } \\
\text { nt) }\end{array}$ & .931 & .146 & & 6.382 & .000 \\
\hline & $\begin{array}{l}\text { Firm } \\
\text { value }\end{array}$ & .059 & .040 & -.076 & -1.475 & .014 \\
\hline
\end{tabular}

Analysis in table $4.5 \mathrm{a}$ and $\mathrm{b}$ was done to test whether firm value has any significant effect on stock return of non-financial listed companies in Kenya.

Firm value had a coefficient of 0.056 and the significance value of 0.014 . At $5 \%$ level of significance I was found that firm value have significant effect on stock return of non-financial listed companies in Kenya. The R-square of the model is $0.76(76 \%)$, this indicates that the model has good fit that substantial variations of stock returns is explained by variations in firm value.

\subsubsection{Impact of Firm Value to stock returns with the presence of firm size and interactions}

Table 4.6a Fitness test for firm value to stock returns with presence of firm size and interactions

\begin{tabular}{|c|c|c|c|c|}
\hline \multicolumn{5}{|c|}{ Model Summary } \\
\hline $\begin{array}{l}\text { Mod } \\
\text { el }\end{array}$ & $\mathrm{R}$ & $\begin{array}{l}\mathrm{R} \\
\text { Square }\end{array}$ & $\begin{array}{l}\text { Adjusted R } \\
\text { Square }\end{array}$ & $\begin{array}{l}\text { Std. Error } \\
\text { of the } \\
\text { Estimate }\end{array}$ \\
\hline 1 & $.877^{\mathrm{a}}$ & .77 & .001 & $\begin{array}{l}.17058065 \\
0432631\end{array}$ \\
\hline 2 & $.889^{\mathrm{b}}$ & .79 & .001 & $\begin{array}{l}.17061196 \\
4959259\end{array}$ \\
\hline \multicolumn{5}{|c|}{ a. Predictors: (Constant), Firm size, Firm value } \\
\hline \multicolumn{5}{|c|}{$\begin{array}{l}\text { b. Predictors: (Constant), Firm size, Firm value, Firm } \\
\text { value } * \text { Firm size }\end{array}$} \\
\hline
\end{tabular}

Table 4.6b $t$ - test for firm value to stock returns with presence of firm size and interactions.

\begin{tabular}{|c|c|c|c|c|c|c|}
\hline \multicolumn{7}{|c|}{ Coefficients $^{\mathrm{a}}$} \\
\hline \multirow{2}{*}{\multicolumn{2}{|c|}{ Model }} & \multicolumn{2}{|c|}{$\begin{array}{l}\text { Unstandardized } \\
\text { Coefficients }\end{array}$} & \multirow{2}{*}{$\begin{array}{l}\text { Standardize } \\
\mathrm{d} \\
\text { Coefficient } \\
\mathrm{s} \\
\text { Beta } \\
\end{array}$} & \multirow[t]{2}{*}{$\mathrm{T}$} & \multirow[t]{2}{*}{ Sig. } \\
\hline & & B & Std. Error & & & \\
\hline \multirow[t]{3}{*}{1} & (Constant) & .900 & .157 & & 5.738 & .000 \\
\hline & Firm value & .050 & .043 & -.064 & 1.149 & .025 \\
\hline & Firm size & .197 & .352 & -.031 & .559 & .007 \\
\hline \multirow[t]{4}{*}{2} & (Constant) & .802 & .189 & & 4.252 & .000 \\
\hline & Firm value & .023 & .052 & -.030 & .446 & .049 \\
\hline & Firm size & 1.690 & 2.062 & .267 & .819 & .013 \\
\hline & $\begin{array}{l}\text { Firm value } * \text { Firm } \\
\text { size }\end{array}$ & .471 & .508 & -.316 & .929 & .004 \\
\hline
\end{tabular}


In model 1, the effect of firm value to stock return was in presence of moderating variable without considering the interaction. The result shows that both the Moderating variable (firm size) and Firm value has significant effects on stock returns. There was improvement in the fitness of this model relative to above model in section 4.5 , where the moderating variable is absent. In model 2 , the interaction of firm value and Firm size is included. Firm value, moderating effect and interactions variables have positive significance to the stock returns. The adjusted R-squared for this model is $79 \%$. Therefore, from these results the presence of earnings per share and its interaction with firm value is significant in explaining the variations on the stock returns.

4.7 Impact of earning per share to stock returns. 4.7.1 Impact of earning per share to stock returns with the absence of Firm size and interactions

Table 4.7a fitness test of earnings per share to stock returns with absence of firm size and interactions

\begin{tabular}{|l|l|l|l|l|}
\hline \multicolumn{3}{|l|}{ Model Summary } \\
\hline $\begin{array}{l}\text { Mod } \\
\mathrm{el}\end{array}$ & $\mathrm{R}$ & $\begin{array}{l}\mathrm{R} \\
\text { Square }\end{array}$ & $\begin{array}{l}\text { Adjusted R } \\
\text { Square }\end{array}$ & $\begin{array}{l}\text { Std. Error } \\
\text { of the } \\
\text { Estimate }\end{array}$ \\
\hline 1 & $.883^{\mathrm{a}}$ & .78 & .71 & $\begin{array}{l}.16933409 \\
3750085\end{array}$ \\
\hline \multicolumn{2}{|l|}{} & & \\
\hline
\end{tabular}

Table 4.7b t- test for earning per share to stock returns with absence of firm size and interactions

\begin{tabular}{|c|c|c|c|c|c|c|}
\hline \multicolumn{7}{|c|}{ Coefficients $^{\mathrm{a}}$} \\
\hline \multirow{2}{*}{\multicolumn{2}{|c|}{ Model }} & \multicolumn{2}{|c|}{$\begin{array}{l}\text { Unstandardized } \\
\text { Coefficients }\end{array}$} & \multirow{2}{*}{$\begin{array}{l}\text { Standardize } \\
\text { d } \\
\text { Coefficient } \\
\text { s } \\
\text { Beta } \\
\end{array}$} & \multirow[t]{2}{*}{$\mathrm{t}$} & \multirow[t]{2}{*}{ Sig. } \\
\hline & & B & Std. Error & & & \\
\hline \multirow[t]{2}{*}{1} & (Constant) & .514 & .072 & & 7.151 & .000 \\
\hline & $\begin{array}{l}\text { Earnings per } \\
\text { share }\end{array}$ & .145 & .051 & .145 & 2.837 & .005 \\
\hline
\end{tabular}

The results in table $4.7 \mathrm{a}$ and $\mathrm{b}$ tested the significant effect of earning per share to stock return of nonfinancial listed companies in Kenya.

Earnings per share had a coefficient of 0.145 and the significance value of 0.005 . At $5 \%$ significance level, earnings per share has significant effect on stock return of non-financial listed companies in
Kenya. The R-square of the model is $0.78(78 \%)$, this indicates that there earning per share explained $78 \%$ variations on stock return hence the model had a good fit.

4.7.2 Impact of earning per share to stock returns with the presence of firm size and interactions.

Table 4.8a fitness test for earning per share to stock returns with presence of firm size and interactions

\begin{tabular}{|c|c|c|c|c|}
\hline \multicolumn{5}{|c|}{ Model Summary } \\
\hline $\begin{array}{l}\text { Mod } \\
\text { el }\end{array}$ & $\mathrm{R}$ & $\begin{array}{l}\mathrm{R} \\
\text { Square }\end{array}$ & $\begin{array}{l}\text { Adjusted R } \\
\text { Square }\end{array}$ & $\begin{array}{l}\text { Std. Error } \\
\text { of the } \\
\text { Estimate }\end{array}$ \\
\hline 1 & $.883^{\mathrm{a}}$ & .78 & .72 & $\begin{array}{l}.16900228 \\
7284362\end{array}$ \\
\hline 2 & $.911^{\mathrm{b}}$ & .83 & .82 & $\begin{array}{l}.16899349 \\
8585919\end{array}$ \\
\hline \multicolumn{5}{|c|}{ a. Predictors: (Constant), Firm size, Earning per share } \\
\hline \multicolumn{5}{|c|}{$\begin{array}{l}\text { b. Predictors: (Constant), Firm size, Earning per share, } \\
\text { Earning per share * firm size }\end{array}$} \\
\hline
\end{tabular}




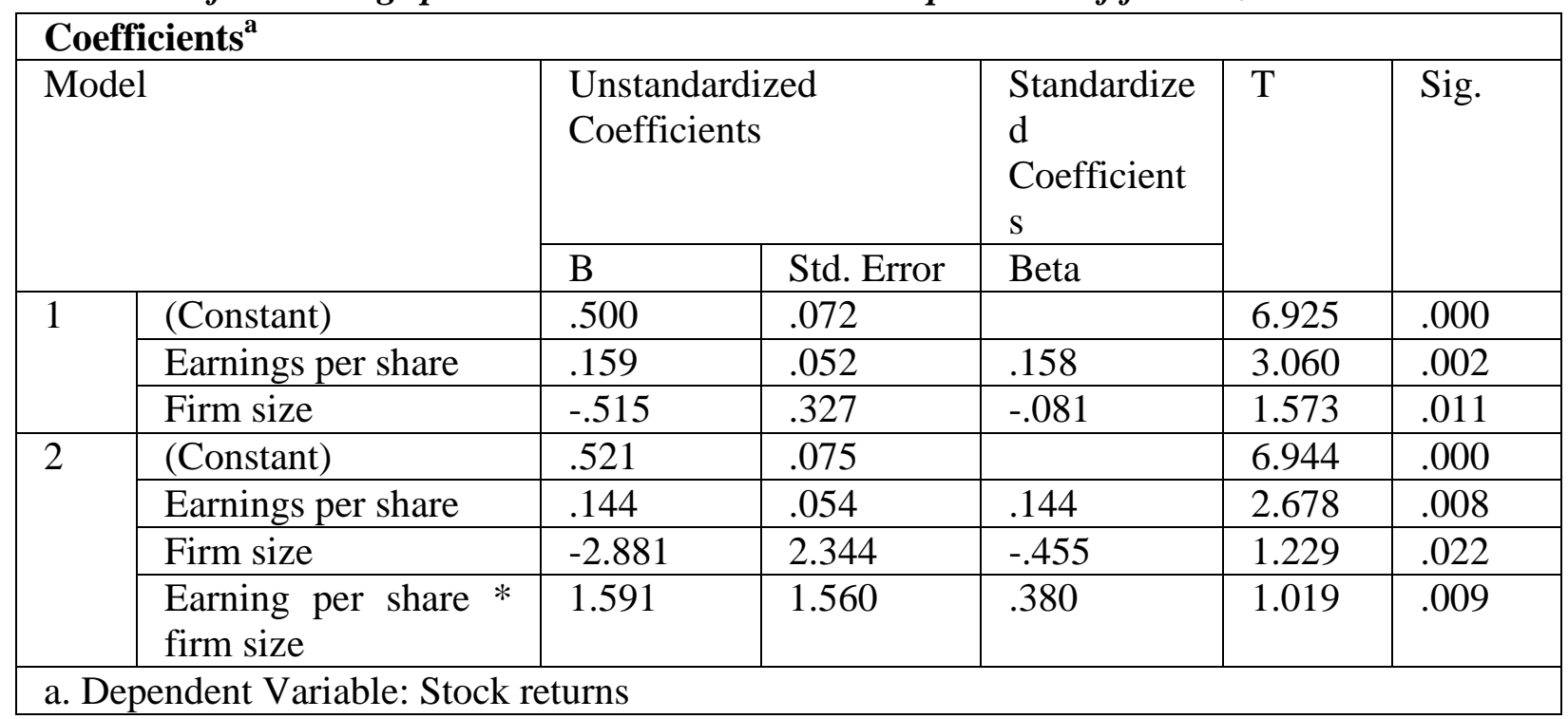

From table 4.8a and $b$, model 1shows the effect of From the panel regression and the Moderated panel regression, it was found that all independent firm value to stock return in presence of moderating variable without considering the interaction. The result shows that both the Moderating variable (firm size) and Firm value has significant effects on stock returns. There was improvement in the fitness of this model relative to model in section 4.6 where the moderating variable is absent. Adjusted R-squared for this model is $77 \%$. In model 2, the interaction of firm value and Firm size is included. Firm value, moderating effect and interactions variables have positive significance to the stock returns. The adjusted R-squared for this model is $79 \%$. Therefore, from these results the presence of earnings per share and its interaction with firm value is significant in explaining the variations on the stock returns.

\subsection{Summary of the Findings}

The descriptive statistics showed that both the independent variables and the dependent variables had high volatility. However, in most of the firms considered, average earning per share data were most centralized. Average earnings per share had least coefficient of variation.

From the unit root test, all the variables used in the study were stationary and therefore were suitable to use without differencing.

From the granger causality test, firm value causes size since there were existence of unidirectional granger causality between the two variables. positive significant effect to performance of stock returns of non-financial firms. With inclusion of firm size and its interaction with each of the independent variables, the fitness of each of the model improved.

\subsection{Conclusion}

The first objective of the study was set to establish the effect of firm value on stock returns of nonfinancial listed companies in Kenya. The findings revealed that firm value has significant effect on stock returns. The study also showed that the precision of the model increased by including the firm size which is the moderating variable.

The second objective of the study was to determine the effect of earnings per share on stock returns of non-financial listed companies in Kenya. Results revealed that earnings per share has significant effect on stock returns. Again the fitness of the model increased when the effect of the earnings per share is studied with presence of firm size.

The third objective of the study was to assess the moderating effect of firm size on the relationship between firm characteristics and stock returns of non-financial listed companies in Kenya. With the presence of moderating variable and its interactions with each independent variable, the models precision are increased as discussed above. 


\subsection{Recommendations}

The study recommends that for non-financial firms to increase the performance of their stock returns, they need to increase the value of their firm. This would in turn lead to more stock returns. The firms also need to increase the earnings per share to increase their stock returns performance. Also increase in firm size through increasing its market share may lead to an increase in stock returns performance.

The MPR model was more suitable for the study of the performance of stock returns of non -financial listed companies in Kenya as it considers both the predictor variables and the moderating variable with their interactions.

\subsection{Recommendations for further research.}

The study recommends future researchers to consider firm characteristics such as stock turnover, current ratio, Price earnings Ratio and Equity ratio which could be presumed to affect stock returns.

\section{References}

[1] Adedoyin, A.O. (2011). Share Price Determination and Corporate Firm Characteristics.

[2] Ahn, S., Denis, D.J., Denis, D.K. (2006). Leverage and investment in diversified firms. Journal of Financial Economics, 79, (2), 317-337

[3] Aksu, M.H. \& Onder, T. (2000). The Size and Book-To-Market Effects and Their Role as Risk Proxies in the Istanbul Stock Exchange. Social Science Research Network

[4] Almajali A. Y., Alamro S.A. \& Al-Soub, Y. Z. (2012). Factors Affecting the Financial Performance of Jordanian Insurance Companies Listed at Amman Stock Exchange. Journal of Management research, 4(2), 266-289.

[5] Amir, A.-Z. (2011). The return of the size anomaly: Evidence from the German stock market. European Financial Management 17(1), 145-182.

[6] Anthony, J. H. (2011). Firm Size, Capital Structure and Earnings Announcement Price Response. JABR, 24(1). doi: 10.19030/jabr. v24i1.1366
[7] Armitage, S. (2014). Corporation tax, leverage and the weighted average cost of capital. The Cost of Capital, 153-180.

[8] Athanasoglou, P. P., Brissimis, S. N., \& Delis, M. D. (2005). Bank-Specific, Industry-Specific and Macroeconomic Determinants of Bank Profitability. Bank of Greece Working Paper, No. 25.

[9] Athanassakos, G (2009). Value vs Glamour stock returns and the value premium. The Canadian experience 1985-2002, Canadian journal of administrative sciences

[10] Barako, D.G. (2007). Determinants of voluntary disclosures in Kenyan companies' annual reports. African Journal of Business Management, 1(5), 113-128.

[11] Belkaoui-Riahi A (2001). Level of multinationality, growth opportunities and size as determinants of analysts' ratings of corporate disclosures. Am. Bus. Rev. 19(2), $115-220$

[12] Bhatnagar, V. K., Kumari, M., \& Sharma, N. (2015). Impact of Capital Structure \& Cost of Capital on Shareholders' Wealth Maximization-A Study of BSE Listed Companies in India. Chanakya International Journal of Business Research, 1(1), 28.

[13] Bhat, P., \& Sumangala, J.K (2012). Impact of earnings per share on market value of an equity share: An empirical study in Indian capital market. Journal of Finance, Accounting and Management, 3(2), 1-14.

[14] Bryman, A., \& Bell, E. (2007). Business research method. Second edition. Oxford university press, UK.

[15] Cassar, G., Holmes, S. (2003). Capital structure and financing of SMEs. Australian evidence. Journal of Accounting and Finance, 43(2), 123-47.

[16] Chongyu, (David) Dang., \& Frank Li. (2015). Measuring Firm Size in Empirical Corporate Finance. Richard Ivey School of Business University of Ontario.

[17] Dimitrov, V. (2011). Capital Structure and Firm Risk. Capital Structure and Corporate Financing Decisions, 59-73. 
[18] Dogan, M. (2013). Does firm size affect firm profitability? Evidence from Turkey. Journal of Finance and Accounting, 4(4), 53-59.

[19] Ecker, F., Francis, J., Kim, I., Olsson, P. M. \& Schipper, K. (2006). A Return-Based Representation of Earnings Quality. The Accounting Review, 81(4), 749 - 780.

[20] Erturk, B., \& Nejadmalayeri, A. (2009). Equity Short Selling and the Cost of Debt. SSRN Electronic Journal. doi:10.2139/ssrn.2147060

[21] Fama, E.F. \&French, K.R. (1992b). The economic fundamentals of size and book-tomarket equity. Working Paper, Graduate School of Business, University of Chicago, Chicago, IL.

[22] Fama, E.F. \& French, K.R. (1993). Common risk factors in the returns on stocks and bonds. Journal of Financial Economics, 33, 3-56.

[23] Ferri, M. G., Jones, W. H. (2009). Determinants of Financial Structure. A New Methodological Approach. Journal of Finance, 34(3), 631-644.

[24] Filbeck, G. \& Krueger, T. (2005). Industry Related Differences in Working Capital Management. Mid-American. Journal of Business, 20(2), 11-18.

[25] Flamini, V., McDonald, C., \& Schumacher, L. (2009). Determinants of Commercial Bank Profitability in Sub-Saharan Africa. IMF Working Paper, 1-30.

[26] Fosu, S. (2013). Capital Structure, Product Competition and firm performance, Evidence from South Africa. University of Leicester (U.K.), Working Paper No.13/11.

[27] Francis, J., LaFond, R., Olsson, P. M. \& Schipper, K. (2004). Costs of Equity and Earnings Attributes. The Accounting Review, 79(4), 967 - 1010

[28] Frazier P.A, Tix A.P, Barron, K.E. (2004). Testing moderator and mediator effects in counseling psychology research. Journal of Counseling Psychology. 51:115-134. doi: 10.1037/0022-0167.51.1.115.

[29] Freeman, R., Ohlson, J. \& Penman, S. (1982). Book Rate-of-Return and Prediction of Earnings Changes. An Empirical Investigation. Journal of Accounting Research, 20, 3-42.

[30] Godwin, Steve. (2015). Protecting your money in the stock market. It's a hesrd game!.Xlibris.

[31] Goetzmann, W. N., \& Massa, M. (2014). Heterogeneity of Trade and Stock Returns. Evidence from Index Fund Investors. SSRN Electronic Journal.

[32] Gomes, Joao F., Leonid Kogan, \& Lu Zhang, (2001). Equilibrium Cross-Section of Returns. Working Paper, The Wharton School at the University of Pennsylvania.

[33] Gwatidzo, T. \& Ojah, K. (2009). Corporate Capital Structure Determinants. Evidence from Five African Countries. The African Finance Journal. Volume 11, Part 1.

[34] Huseyin, G., (2008). Value versus growth. Time-varying expected stock returns. Journal of Portfolio Management, 11, 9-11.

[35] Hvide, H. K., \& Moen, J. (2007). Liquidity Constraints and Entrepreneurial Performance. Retrieved March 2015, from ssrn.com: http://ssrn.com/abstract=1012012

[36] Iswatia, S., \& Anshoria, M. (2007). The Influence of Intellectual Capital to Financial Performance at Insurance Companies in Jakarta Stock Exchange (JSE). Proceedings of the 13th Asia Pacific Management Conference. Melbourne

[37] Jensen M. C. (1986). Agency Costs of Free Cash Flow, Corporate Finance, and Takeovers. American Economic Review, 76(2), 323-329

[38] Khalid, S., Ali, A., Baloch, M.Q., and Ali, N. (2014). Analysis of the impact of leverage on various measures of corporate performance, using Arellano and Bond dynamic panel data estimation technique. Abasyn Journal of Social Sciences, 7(1), 1-10.

[39] Khurshed, A. (2009). The long run performance of IPOs. Managerial Finance, 33(6), 401-419.

[40] Kibet, B., Kibet, L., Tenai, J. \& Mutwol, M. (2011). The Determinants of Leverage at the Nairobi Stock Exchange, Kenya. The Second 
Asian Business and Management Conference 2011 Osaka, Japan.

[41] Kumar, M. \& Sehgal, S. (2004). Company Characteristics and Common Stock Returns. The Indian Experience. Investment Management and Financial Innovations, 4

[42] Lang M, and Lundholm R (2003). Crosssectional determinant of analyst ratings of corporate disclosures. J. Account. Res. 31(2): 246-71.

[43] Liargovas, P., \& Skandalis, K. (2008). Factor affecting firms' financial performance. The Case of Greece. Athens: University of Peloponnese Press.

[44] Maina, L \& Kondongo, O. (2013). Capital Structure and Financial performance in Kenya. Evidence from Firms Listed at the Nairobi Securities Exchange. Paper presented at the Jomo Kenyatta University of Science and Technology, SHRD Research Conference, Kenya, 238-246.

[45] Mwangi, L. W., Muathe, S.K., \& Kosimbei, G. (2014). Relationship between Capital Structure and Performance of Non-Financial Companies Listed in the Nairobi Securities Exchange. Kenya. Global Journal of Contemporary Research in Accounting, Auditing and Business Ethics, 1(2), 72-90.

[46] Nairobi Stock Exchange (2015). Company data. Hutchings Biemer. Trading Day: 22 May 2015

[47] Nunes, P. J., Serrasqueiro, Z. M. and Sequeira, T. N. (2009). Profitability in Portuguese service industries: a panel data approach. The Service Industries Journal, 29(5), 693- 707.

[48] Omondi, M.M. \& Muturi, W. (2013). Factors Affecting the Financial Performance of Listed Companies at the Nairobi Securities Exchange in Kenya. Research Journal of Finance and Accounting, 4(15), ISSN 2222-1697 (Paper) ISSN 2222-2847 (Online)

[49] Owusu-Ansah S (2008). The impact of corporate attributes on the extent of mandatory disclosure
[50] Penman, S. H. (2003). Financial Statement Analysis and Security Valuation. 2nd Ed. US: McGraw Hill.

[51] Perez, Q., G., \& Timmermann, A. (2010). Business cycle asymmetries in stock returns: Evidence from higher order moments and conditional densities. FMG Discussion Papers.

[52] Perez, Q., Gabriel., \& A. Timmermann, (2000). Business cycle asymmetries in stock returns. Evidence from higher order moments and conditional densities. FMG Discussion Papers.

[53] Pietrovito, F. (2012). Investment Decisions, Price-Earnings Ratios and Finance. Evidence from Firm-Level Data. SSRN Electronic Journal. doi:10.2139/ssrn.1342221

[54] Preacher, K. J., Rucker D. D., \& Hayes, R.F. (2007). Addressing moderated mediation hypotheses. Theory, methods, and prescriptions. Multivariate Behavioral Research, 42, 185-227.

[55] Safi, U.K. \& R. Faisal, (2008). Trading volume and stock returns. Evidence from Pakistan's stock market. International Review of Business Research Papers 4(2), 151-162.

[56] Saunders, M., Lewis, P., \& Thornhill, A. (2007). Research methods for business student. 4th edition. Prentice Hall, UK.

[57] Schaeffler, S. (2013). An Evaluation of Different Approaches to Capital Structure Regulations. Electronic Journal. doi:10.2139/ssrn.2090157

[58] Seetharaman, A., \& Raj, R.J. (2011). An empirical study on the impact of earnings per share on stock prices of a listed bank in Malaysia. The international Journal of applied economics \& Finance.5 (2), 114126.

[59] Shiller R. J., (2005). Irrational Exuberance. Second edition. Princeton University Press, Princeton NJ.

[60] Shleifer, A., \& Vishny, R. W. (1997). The Limits to arbitrage. Journal of Finance, 529(1), 35-55. 
[61] Simerly, R., \& Li, M. (2000). Environmental dynamism, financial leverage and performance: A theoretical integration and an empirical test. Strategic Management Journal, 21(1), 31-49.

[62] Simlai, P. (2009). Stock returns, size, and book-to-market equity. Studies in Economics and Finance, 26(3), 198 - 212

[63] Singh, A. (2009). Should Africa Promote Stock Market Capitalism? Journal of International Development, 11, 343 - 365 .

[64] Sloan, R. G. (1996). Do Stock Prices Fully Reflect Information in Accruals and Cash Flow about Future Earnings? The Accounting Review, 71(3), 289 - 315.

[65] Tahir, S.H., Sabir, H.M., Alam, T., \& Ismail, A. (2013). Impact of Firm's Characteristics on Stock Return: A Case of Non-Financial Listed Companies in Pakistan. Asian Economic and Financial Review, 2013, 3(1):51-61

[66] Timmer, Jan (2011). ''Understanding the Fed Model, capital structure and then some."

[67] Tucker, J. W. \& Zarowin, P. A. (2006). Does Income Smoothing Improve Earnings Informativeness? The Accounting Review, 81(1), $251-270$.

[68] Tversky, A., \& Kahneman, D. (1974). Judgement under Uncertainty. Heuristics and Biases. Science, 185, 1124-1131.

[69] Umer, U. M. (2014). Determinants of Capital Structure. Empirical Evidence from Large Taxpayer Share Companies in Ethiopia. International Journal of Economics and Finance, 6(1), 53-65.

[70] Velez-Pareja, I. (2012). The Weighted Average Cost of Capital (WACC) for Firm Valuation Calculations. A Reply. SSRN Electronic Journal.
[71] Velnampy, T. \& Anojan, V. (2014). Capital Structure, Liquidity Position and Their Impact on Profitability. A study of Listed Telecommunication Firms in Colombo Stock Exchange, Sri Lanka. Research Journal of Finance and Accounting, 5(9), 131- 139.

[72] Wahyudi, I. \& Sani, G.A. (2014). Interdependence between Islamic capital market and money market. Evidence from Indonesia. Borsa Istanb Rev, 14 (1) (2014), pp. 32-47

[73] Wallace RSO, Naser K, \& Mora A (2004). The relationship between the comprehensiveness of corporate annual reports and firm specific characteristics in Spain. Account. Bus. Res. 25(97), 41-53

[74] Watson, J. (2005). The Association of various earnings and cash flow measures of firm performance and stock returns. School of accounting, University of Technology, Sydney.

[75] World Bank (2014). Market capitalization of listed companies (\% of GDP).

[76] Xiao-Ming, L. and W.S. Xiaoguang, C., (2010). Quantum fisher information flow and non-markovian processes of open systems. In Physical Review 82(4).

[77] Yuqi, L. (2007). Determinants of Banks' Profitability and Its Implication on Risk Management Practices. Panel Evidence from the UK. The University of Nottingham.

[78] Zaighum, I. (2014). Impact of Macroeconomic Factors on Non-financial firms' Stock Returns. Evidence from Sectorial Study of KSE-100 Index. Journal of Management Science Vol. 1(1), 35-48.

[79] Zurcher, Ulrik Ardal (2014). " The effects of interest rates on equity markets that allows share repurchases", 